\title{
Impact of improper storage and installation of glazed fire rated walls on their performance
}

\author{
Jacek Kinowski ${ }^{1}$, Pawet Sulik ${ }^{1, *}$, and Bartłomiej Sęltak ${ }^{1}$ \\ ${ }^{1}$ Instytut Techniki Budowlanej, Zakład Badań Ogniowych, 00-611 Warszawa, ul. Filtrowa 1, Polska
}

\begin{abstract}
The article describes issues related to fire resistance of glazed elements. The influence of the method of storage, transport, seasoning, manufacturing defects, irregularities in the scope of fixing the glass and the thickness of the glass sheet on the effectiveness of the partition in terms of fire resistance is presented.
\end{abstract}

\section{Introduction}

The use of glazed surfaces in modern architecture keeps increasing [1-4]. Elements in which glass is the dominant material are installed both vertically [5-9] and at an angle or horizontally [10,11]. Under Polish construction law [12] these barriers are frequently required to have a specific fire rating. That is why Polish construction market is very characteristic for the particular care paid to the properties of applied material solutions as regards their behaviour during a fire. It is caused not only by the demanding requirements set out in the Polish construction regulations but also by a well-functioning system of checking products and entire assemblies during their introduction to the market and installation. However, in the case of glazed walls, both those for internal and external use there is a risk that the real performance properties of elements may deviate from the declared ones. This is reflected by occasional failures of these structures during fire tests, which are particularly devastating when unexpected. It is this issue that this article is devoted to, based on examples of failed fire resistance tests.

\section{Fire resistance tests}

Fire resistance of a given glazed barrier is impossible to determine based on the element's design or other technical documentation. The only way to determine real fire resistance class is to perform tests according to a relevant test standard. In every document of this type specific requirements are defined regarding the construction of the test assembly, type of mounting and the test procedure, including the heating method and placement of thermocouples measuring increase of temperature on the unexposed surfaces of test specimens.

The test specimens of glazed walls should be perfectly representative of the structures used in reality or constructed in a way which allows the widest possible scope of application

\footnotetext{
*Corresponding author: p.sulik@itb.pl
} 
of the test results. In the former case, the element mounted on the test station is identical in its structure and dimensions with that which is intended to be installed in the building, and in the latter case - the tested element is one whose construction scheme differs from what is used in practice, but application of different combinations of connections and proper dimensions allows to extrapolate the results onto a range of similar structures.

The number of fire tests needed to rate a glazed wall depends on the intended range of applications and on the wall's structure. Glazed curtain walls, depending on the expected fire resistance class may be tested using fire exposure from the inside or from the outside. In the case of glazed partition walls with a symmetrical cross-section one test is sufficient, while for asymmetrical walls it is necessary to check fire resistance with exposure from each side. Glazed doors should be checked with exposure to fire from the side of hinges and from the side opposite to the hinges.

During a fire resistance test the fire conditions are simulated with the right heating curve. Partition walls and doors, as mostly indoor elements, are tested using the standard curve representing a fully developed fire initiated indoors. A different principle applies to curtain walls - in the scenario assuming heating from the inside the temperature should be consistent with the standard curve and in the scenario assuming heating from outside, the temperature corresponding to a fire outside (considerably less severe) should be consistent with the external fire exposure curve; it is, however, acceptable to test a glazed curtain wall specimen from outside using the standard curve. Heating curves are presented in Fig. 1.

A fire resistance test checks performance criteria such as integrity, insulation, radiation and resistance to mechanical actions.

Methodology of fire resistance testing of glazed elements and description of particular performance criteria has been extensively covered in academic literature, e.g. [13-16].

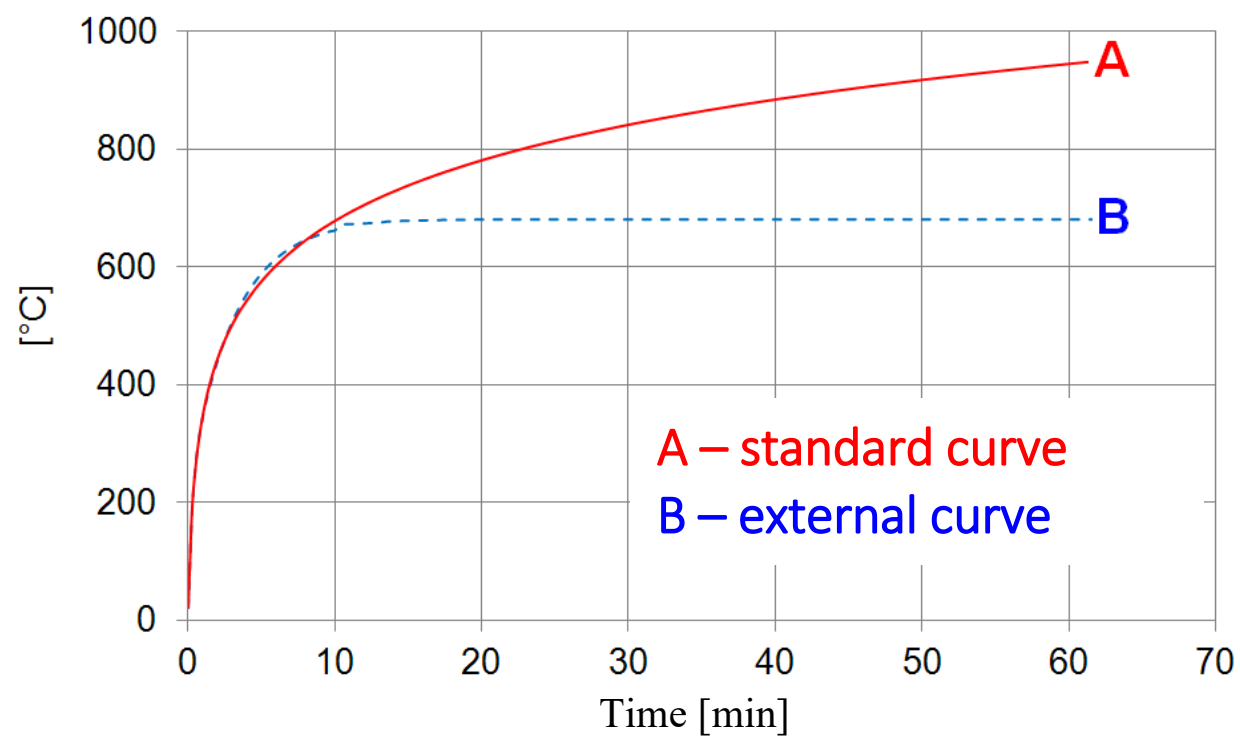

Fig. 1. Heating curves 


\section{Transport and storage}

The manner in which the glazed filling elements of the test specimen were transported and subsequently stored is an important factor which may influence the performance during a simulated fire. The storage time being mentioned after the transport is intentional. Manufacturers are well aware that these products are vulnerable to particular weather conditions. This awareness is not always properly acted on when it comes to unloading and "temporarily" leaving the material in any free space, not necessarily prepared for the purpose.

According to standard guidelines for layered fire resistant glazing (Fig. 2) most common on the market (single or multiple-pane), it should be treated with care to ensure that the glazing:

- is stored in a dry, protected and ventilated room,

- is not exposed to sunlight,

- is stored at temperatures between $-10^{\circ} \mathrm{C}$ and $+45^{\circ} \mathrm{C}$ (Fig. 3);

- is positioned vertically, both during transport and storage.

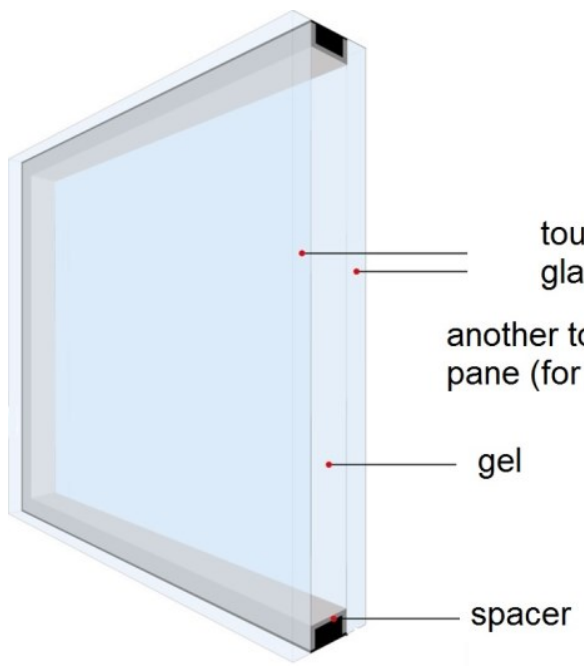

toughened glass pane

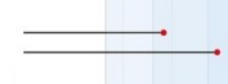

another toughened glass pane (for DGU units)

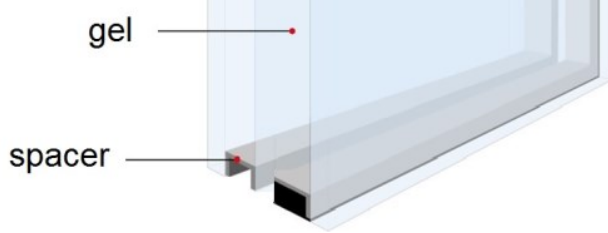

Fig. 2. Structure of typical layered fire glazing.

A scenario where glazing is stored incorrectly is particularly dangerous, as the chemical changes which occur when glass intended to be used indoors is exposed to sunlight (and temperature) are frequently impossible to see with the naked eye. Fig. 5 shows photographs taken during a fire resistance test of a mullion-free glazed partition wall and progressing loss of insulation on the element's surface. The same test specimen before the test is shown in Fig. 4. Incorrect behaviour of the gel in this area, according to a later "investigation" was most likely caused by the glazing being stored for (only) 5 days without cover outside the test building in sunny, warm July weather. 


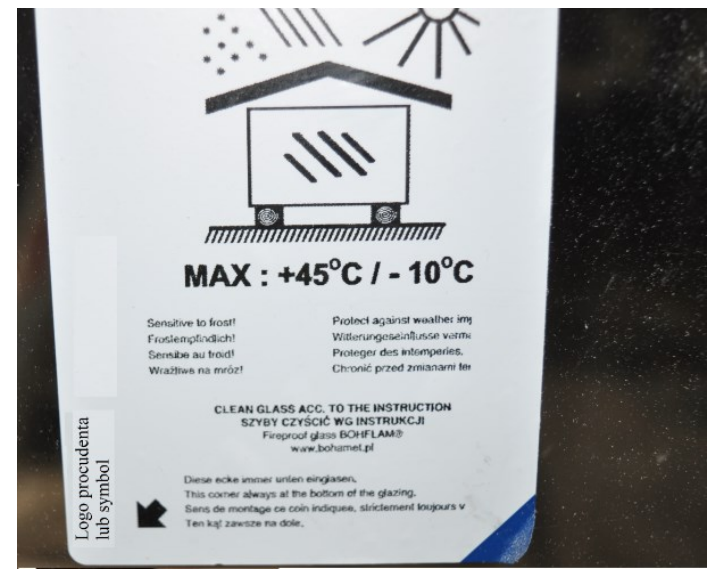

Fig. 3. Image of the standard label put on glass by manufacturers.

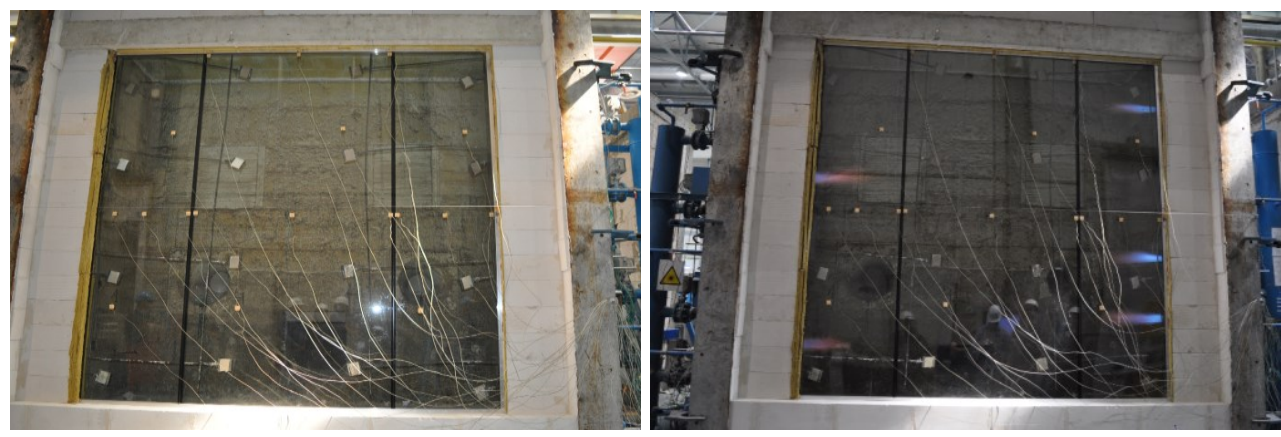

Fig. 4. Mullion-free glazed wall test specimen before a fire resistance test. Building Research Institute's archive.
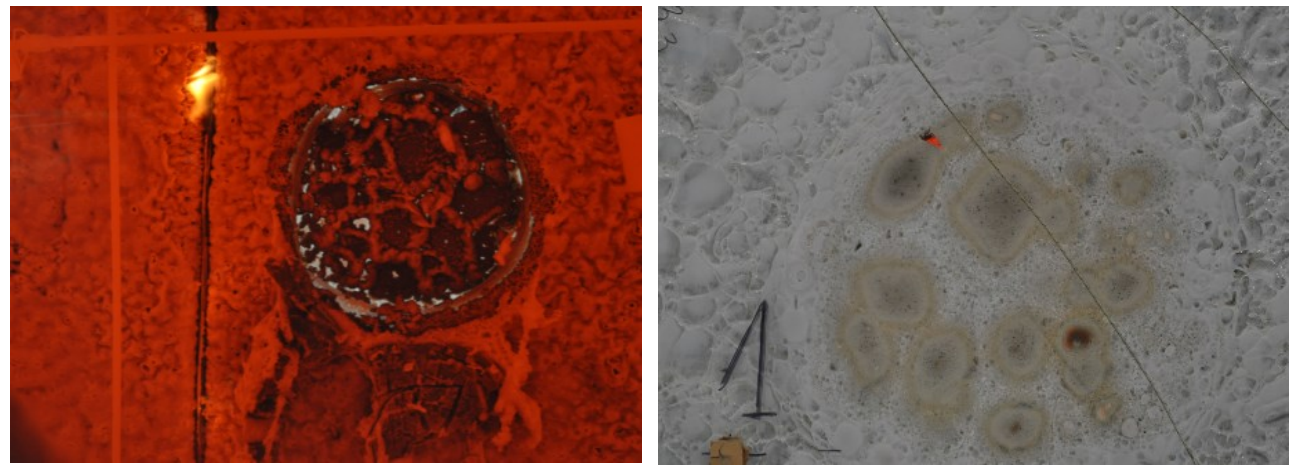

Fig. 5. Photographs of fragments of exposed and unexposed surfaces of the glass at 26 minutes of a fire resistance test carried out on a mullion-free glazed wall. Building Research Institute's archive. 

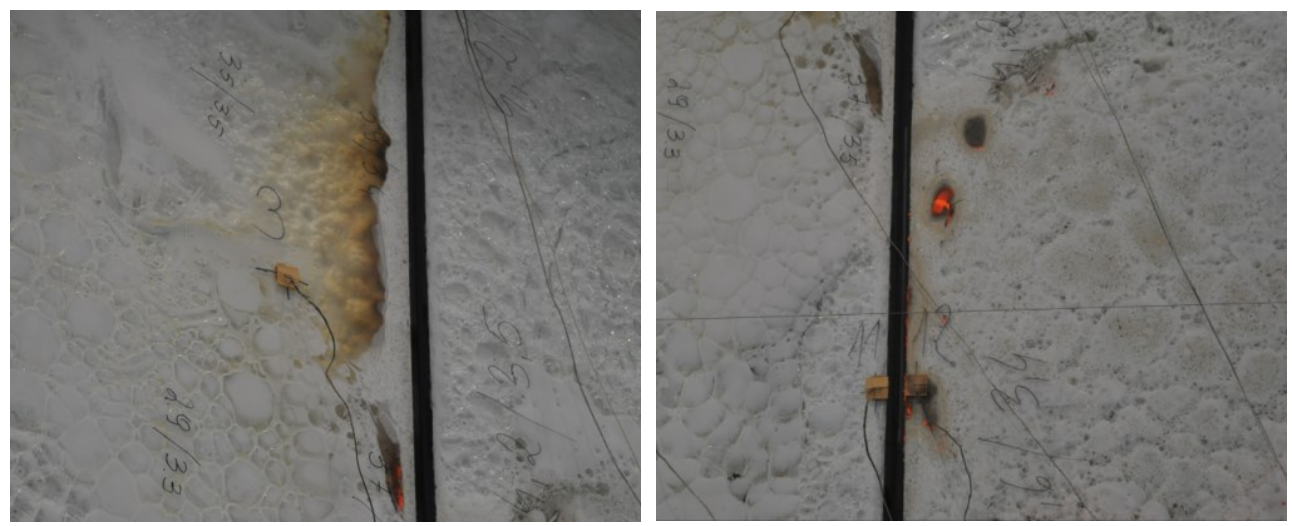

Fig. 6. Photographs of fragments of unexposed surfaces of the glass at 31 minutes of a fire resistance test carried out on a mullion-free glazed wall. Building Research Institute's archive.

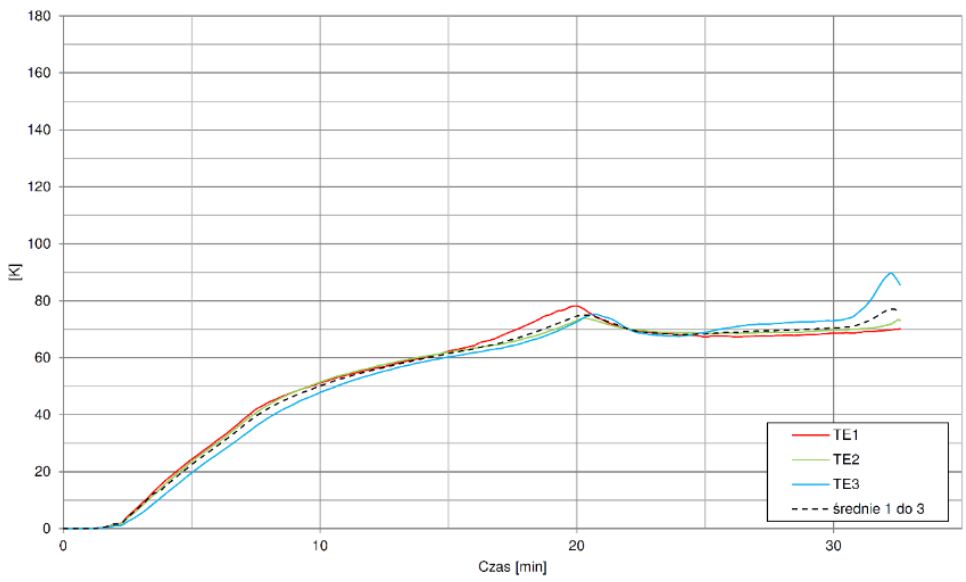

Fig. 7. Graph of temperature increase on the unexposed side of the test specimen - readings from thermocouples measuring maximum and average temperature on the glass pane shown in photographs in Fig. 5. Building Research Institute's archive.

As can be seen on the graph in Fig. 7, the increase in temperature recorded by thermocouples 1-3 for measuring average temperature is moderate in value - far below maximum accepted by standards as safe. This does not change the fact that due to local scorches on the glass, at which the temperature increase, measured with a special mobile thermocouple, exceeded $180 \mathrm{~K}$, the specimen failed the insulation criterion before assumed time.

The graph in Fig. 8 confirms the possibility of exceeding limit temperature at points where the gel inside the fire glazing was scorched. Increase recorded on thermocouples 11 and 12 located near each other (photograph on the right in Fig. 6) show differences in temperature increase at the point where the gel performs correctly and where it was scorched. 


\section{Conditioning}

Aside from technical conditions of transport and storage, for some technical solutions characteristic for specific types of glazing from specific manufacturers a parameter that cannot be disregarded is conditioning time. Testing experience shows that glazing prepared directly before fire tests performs visibly worse than the same one that was able to "rest" after assembly for a sufficient amount of time before the test. Typically two to three weeks allows the glazing to reach its nominal parameters, which is usually sufficient from the perspective of installation on the site, which is often over a month before the building is handed over for use.

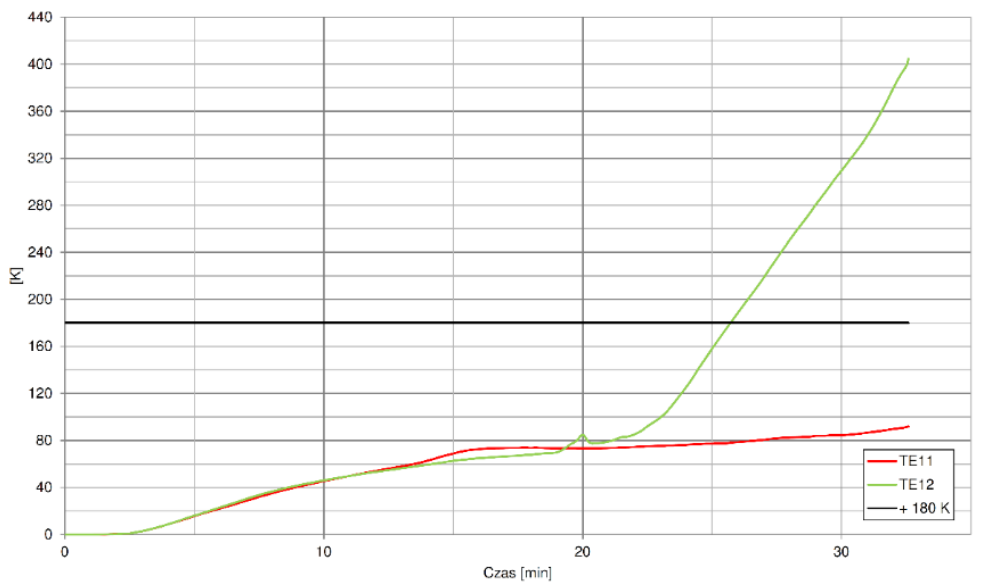

Fig. 8. Graph of temperature increase on the unexposed side of the test specimen - readings from thermocouples measuring maximum temperature at faults shown in photographs in Fig. 6. Building Research Institute's archive.

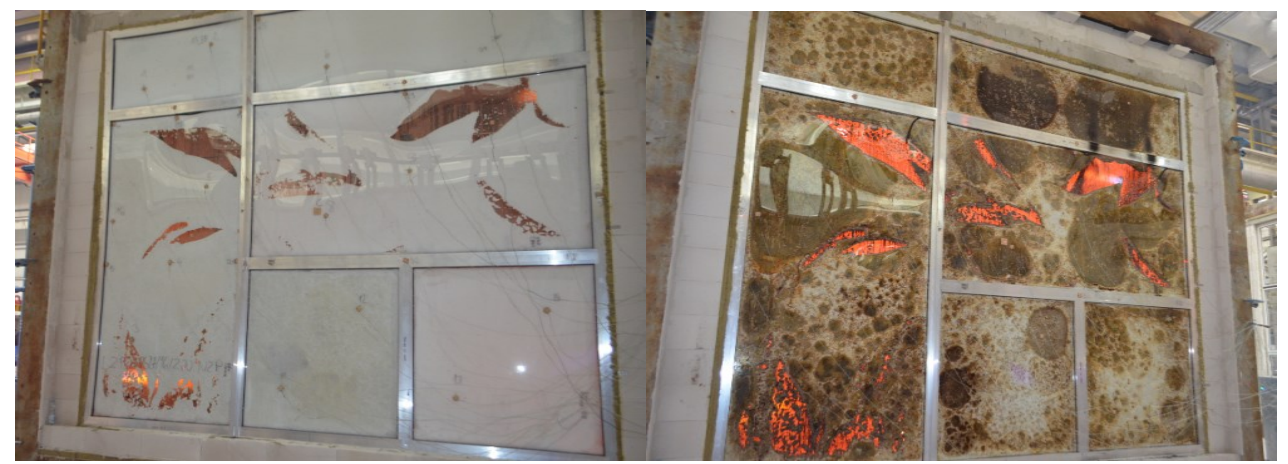

Fig. 9. Photographs of unexposed surfaces of a partition wall at 6 minutes (left) and 16 minutes of a fire resistance test. Building Research Institute's archive. 


\section{Manufacturing defects}

Similarly to the scenario described in the previous item, occasionally the fire test exposes manufacturing defects of the glazing, which a consumer, or even a qualified employee of an accredited laboratory, is unable to spot. According to a declaration from the manufacturer, an entire batch of faulty glazing is then recalled from the market as it may pose fire safety hazard in a building; additionally, measures are taken to improve the consistency of characteristics of components. The process with highest difficulty is undoubtedly application of the gel, which requires specialised equipment to be distributed evenly between glass panes.

In contrast to graphs presented in Fig. 7 and 8 above, we can see a rapid increase of temperature in the first minutes of the test, indicating a technological problem of transparent filling.

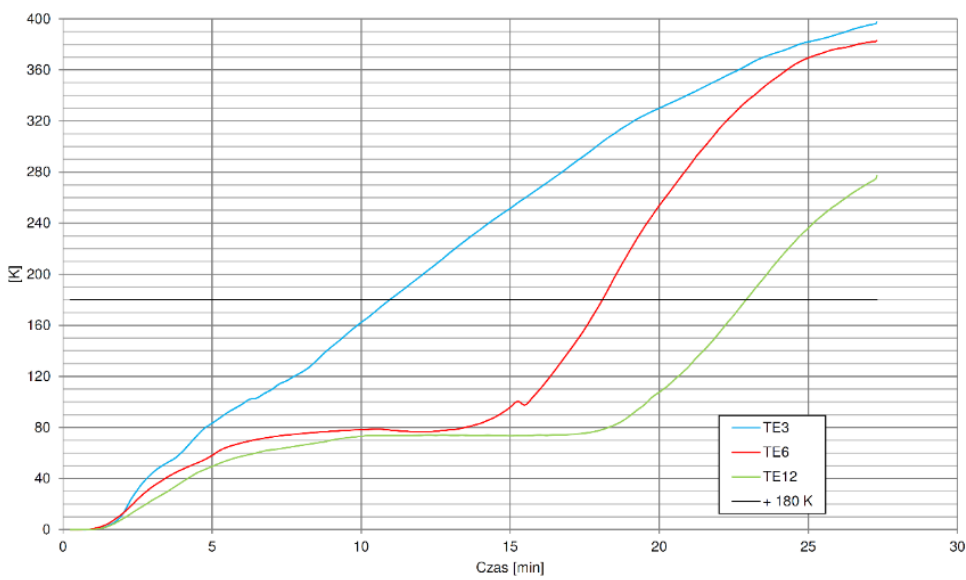

Fig. 10. Graph of temperature increase on the unexposed side of the test specimen - readings from thermocouples measuring maximum and average temperature on the glass pane shown in Fig. 9.

\section{Incorrect mounting of the glass}

Another defect a glazed structure may hold lies in the mounting of the glass pane. Human error and occasional, but often hard to define material defects cause the tested structure to perform unexpectedly in the test. Important factors are not only the installers' precision but also strict adherence to technical procedure for assembling a given structure. A seemingly insignificant change, e.g. in the distance of glass attachment points, lack of continuity of the intumescent gasket or changing its manufacturer or type of material may cause adverse consequences. 


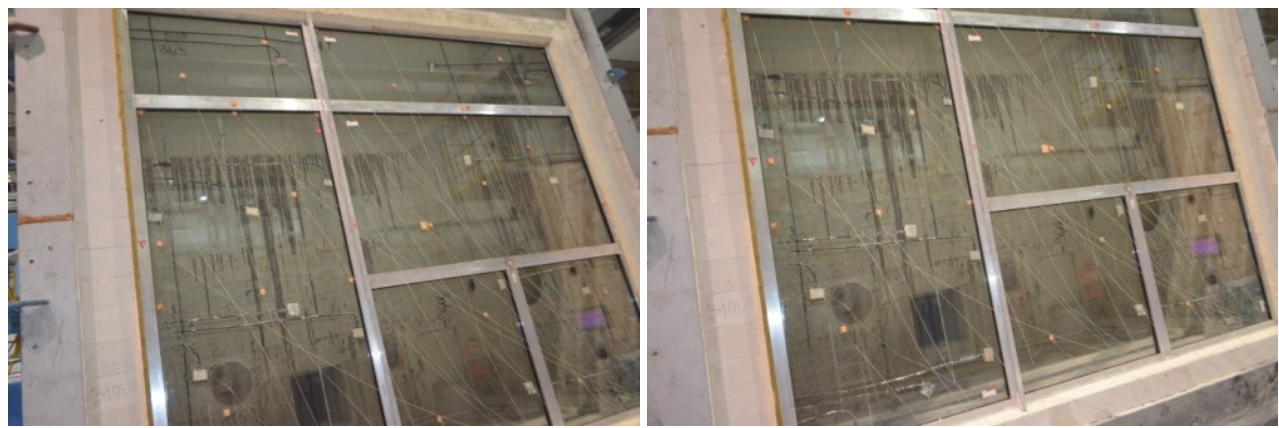

Fig. 11. Photographs of unexposed surface of a partition wall before fire resistance test. Building Research Institute's archive.

The graph above presents a very similar situation to that shown for a test on a mullionfree wall - regular increase and moderate values. However, due to problems with improper mounting of the glazing the test failed. Details of the test specimen - non-load-bearing glazed wall with profiles - aluminum; the analysed area is shown in Fig. 14.

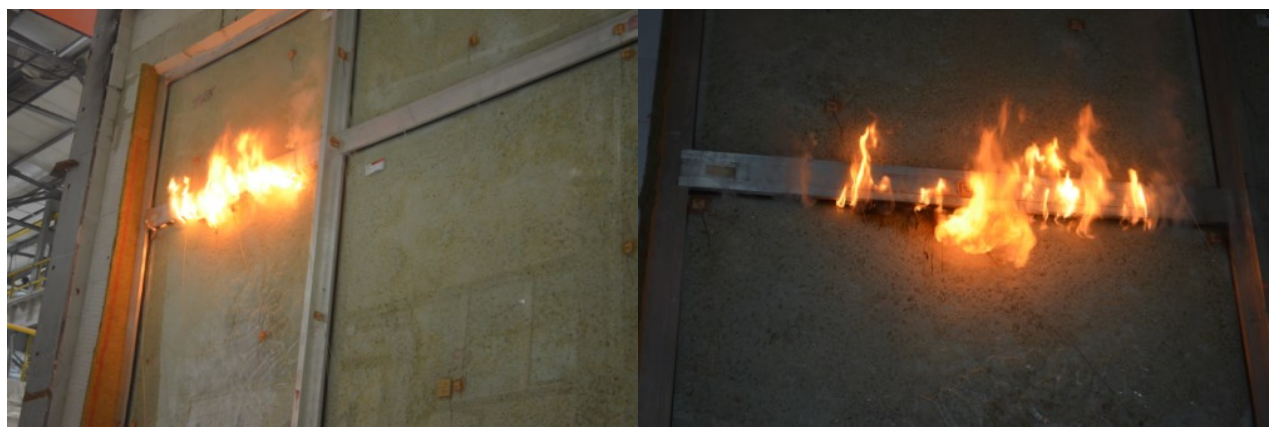

Fig. 12. Photographs of fragments of unexposed surface of the glass at 14 minutes (left) and 18 minutes of a fire resistance test carried out the test specimen presented in Fig. 11. Building Research Institute's archive.

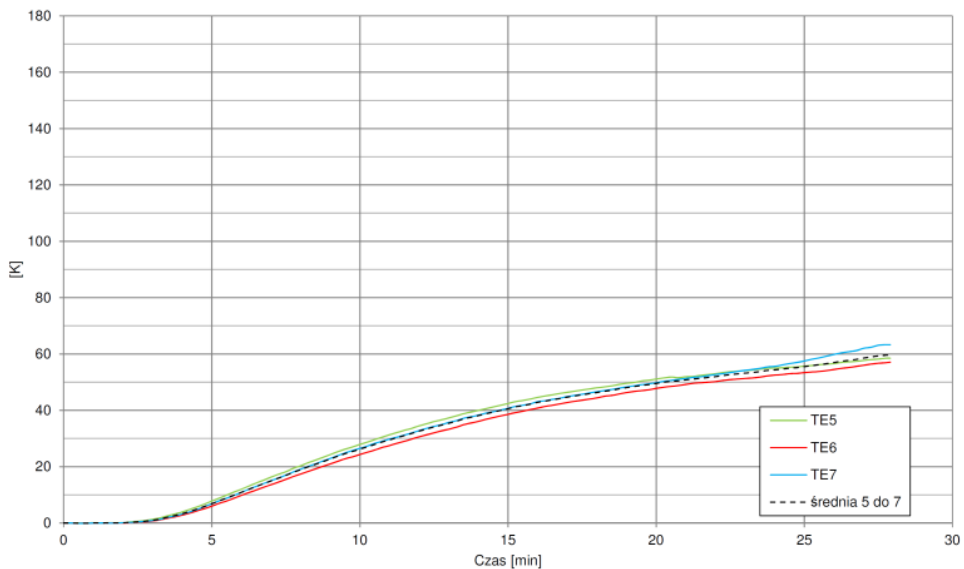

Fig. 13. Graph of temperature increase on the unexposed side of the test specimen - readings from thermocouples measuring maximum and average temperature on the glass pane shown in photographs in Fig. 11. and 12 (glass under the beam). 

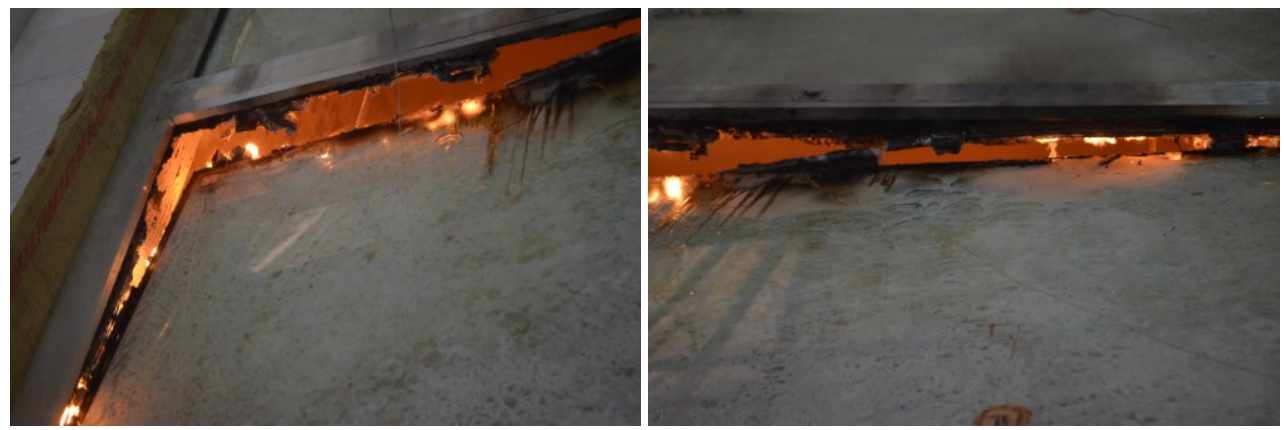

Fig. 14 Photographs of fragments of the test specimen after tests are shown in Fig. 11 and 12. Building Research Institute's archive.

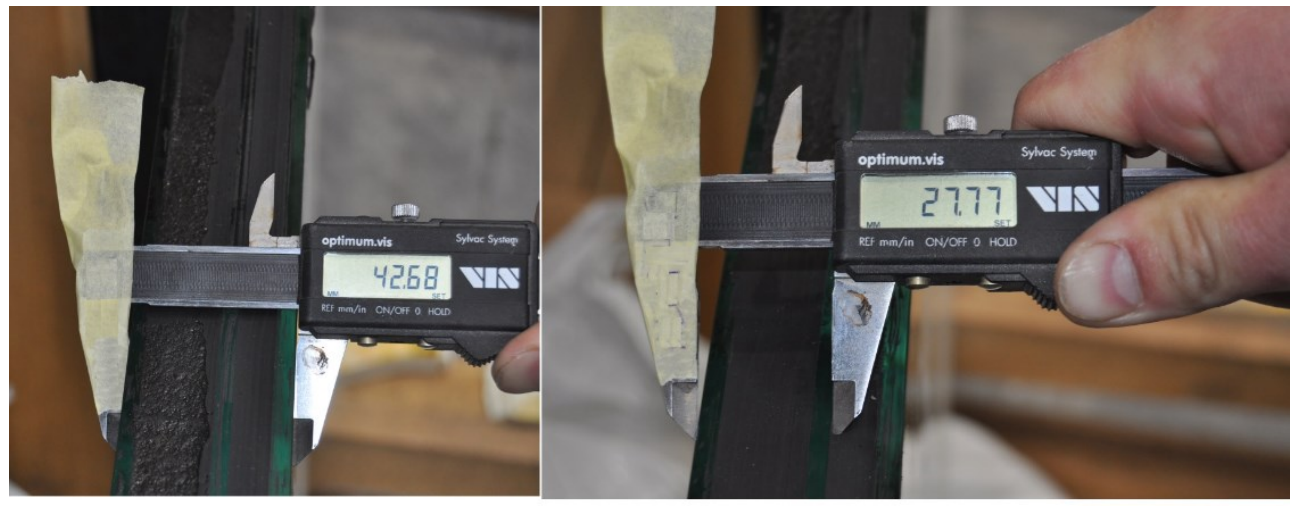

Fig. 15. Photographs of measurements of a fire resistant glass unit and glass pane. The measured difference from the nominal value was $2.77 \mathrm{~mm}$. Building Research Institute's archive.

\section{Thickness of the fire rated glass pane}

A defect that is equally difficult to identify before installation of a piece of glazing is an uneven or insufficient thickness of the fire resistant glazing. In the case of multiple-pane glass units there is basically no more possibility to check the thickness of the glazing responsible for fire resistant characteristics of the assembly. Test experience with single layered glazing suggests that differences in thickness of up to $3 \mathrm{~mm}$ are possible between panes which are theoretically identical (same type and manufacturer). Coupled with the fact that 5-7 $\mathrm{mm}$ of gel is often the only difference between glazing used for structures with declared fire resistance class EI 30 and EI 60, this shows the extent of the issue.

Contrary to the other cases. this kind of defect does not have to cause a spectacular end to the test. Often it is enough for the temperature increase on the unexposed side to exceed the acceptable limit for the specimen to be disqualified under the classification rules. 


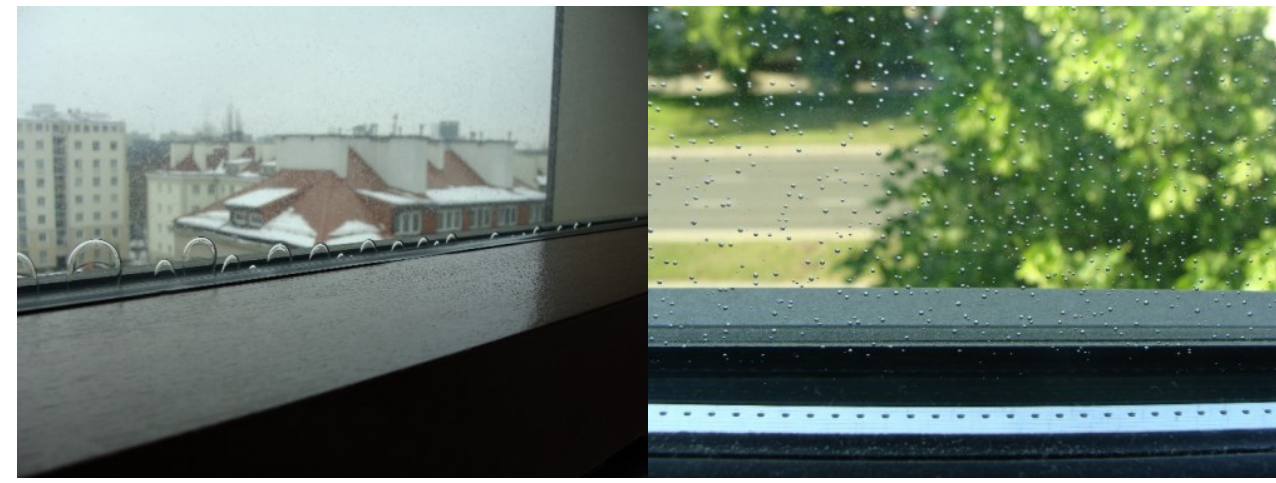

Fig. 16. Photographs of fire resistant glazing with visible defects. Building Research Institute's archive.

\section{Conclusions}

Statistically, the possibility for a fire to occur, in particular a large fully developed fire, is low. This means that many elements responsible for fire safety, and especially fire resistance, fulfil their role "on standby". A great number of elements, including masonry walls or concrete walls have much greater certainty of meeting fire requirements than glazed elements, which hardly differ between one another and it is hard to distinguish a fire resistant glazed element from one with forced entry protection. At a time of a fire, if those elements are on the border of fire compartment, they play a critical role, dividing the building into safe areas, to which people can evacuate and limiting the spread of fire throughout the building. This kind of elements allow people to survive fire and limit material damage. For this reason their performance is extremely important.

In the case of fire resistant glazed elements there are two possible scenarios. The first concerns elements in which damage is visible and repairable, usually though replacement of the glazing (Fig. 16) and the second when there is no visible damage but a significant risk exists that a given barrier will not provide the expected safety parameters. In the latter case non-compliance with the requirements can only be determined through tests, using destructive test methods. The test results presented above prove that many factors have significant impact on performance of glazed fire resistant structures; they include correct transport, properly selected storage place and meticulous installation, as even slight imperfections may pose a serious risk in an emergency situation such as fire [17, 18], which may result in a catastrophe and criminal charges for responsible persons. 


\section{References}

1. W.K. Chow, Y. Gao, C.L. Chow, J. Appl. Fire Sci., 16(3), pp. 201-223 (2006)

2. A. Plotnikov, Vestn. MGSU, 11, pp. 7-15 (2015)

3. B. Siebiert, IABSE Congr. Rep., 17(9), pp. 342-343 (2008)

4. B. Sędłak, J. Kinowski, D. Izydorczyk, P. Sulik, Appl. Struct. Fire Eng., pp.472-477 (2016)

5. B. Sędłak, P. Sulik, Szkło i Ceram., 66(5), pp. 8-10 (2015) [In Polish]

6. J. Kinowski, P. Sulik, B. Sędłak, Bezpieczeństwo i Technika Pożarnicza, 42(2), pp. 135-140 (2016) [In Polish]

7. B. Sędłak, P. Sulik, J. Kinowski, Bezpieczeństwo i Technika Pożarnicza, 42(2), pp. 167-171 (2016) [In Polish]

8. A. Borowy, Inżynier Budownictwa, 11, pp. 64-68 (2013) [In Polish]

9. A. Borowy, Požární ochrana, pp. 15-17 (2014) [In Polish]

10. P. Roszkowski, B. Sędłak, Świat Szkła, 19(12), pp. 46-51 (2014) [In Polish]

11. P. Roszkowski B. Sędłak, Świat Szkła, 16(6), pp. 50-52 (2011) [In Polish]Rozporządzenie Ministra Infrastruktury z dnia 12 kwietnia 2002 r. w sprawie warunków technicznych jakim powinny odpowiadać budynki i ich usytuowanie (Dz. U. Nr 75, Poz.690) [In Polish]

12. B. Sędłak, P. Sulik, Świat Szkła, 23(2), pp. 34-38 (2018) [In Polish]

13. B. Sędłak, P. Sulik, Świat Szkła, 23(3), pp. 26, 28-30, 32-33 (2018) [In Polish]

14. B. Sędłak, P. Sulik, Świat Szkła, 23(4), pp. 29-30, 32-33, 35 (2018) [In Polish]

15. B. Sędłak, P. Sulik, Świat Szkła, 23(5), pp. 28-30, 32 (2018) [In Polish]

16. P. Sulik, Materiały Budowlane, 8, pp. 70-73 (2011) [In Polish]

17. P. Sulik, P. Wróbel, Materiały Budowlane, 9, pp. 73-75 (2011) [In Polish] 